Beftanbtbeile der Eqmintbobueu:

Eamenbuillen

(oiefe entbalten Fajer

4.60

Gallertfăture

4,60

in $98 a f f r$ lozlide Eubfans,

Etåtruepl und Epuren von

Legumin

1,17

Gtárfmevl

Zegumin

7,00

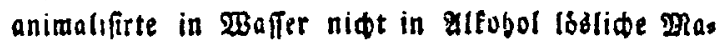

terie

Ballertiaure wit einem Sinterbalt oun Eegurain und

Amplum

fette wenig geförbte Draterie

pulpsfes Efelett.

unfrpfallifirbaren Buder.

Ialis und Ralfpoeppat, Ralfcarbonat, Epuren eis

ner organifden surd stali dus zbeil gefattigten

Daterie und Berlup

Buffer
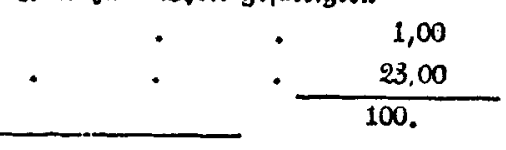

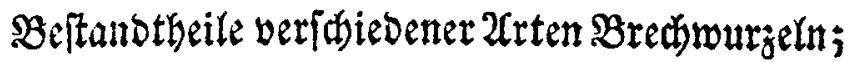
von

$\mathfrak{M} \mathfrak{g g} e=\mathfrak{P}_{\mathfrak{l}}$ *).

Psychotria emetica.

Delig = fettige Materie

Emxtin .

Wads

(S)

Erårtmebl

Gafer

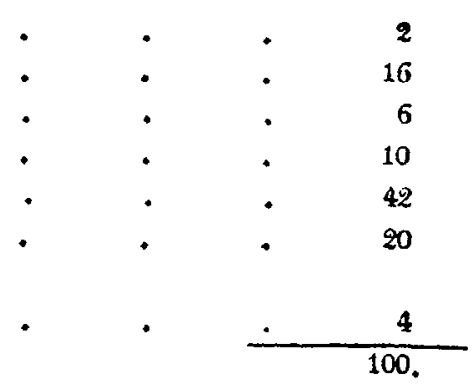

(5alludfäure, Epuren

Derluft

*) Diss. med. inaug. de multiplici emeticorum in medicina XXIV $\mathfrak{B D}$. $1 \mathrm{Sft}$. 
Der bolzige rgeil entbielt:

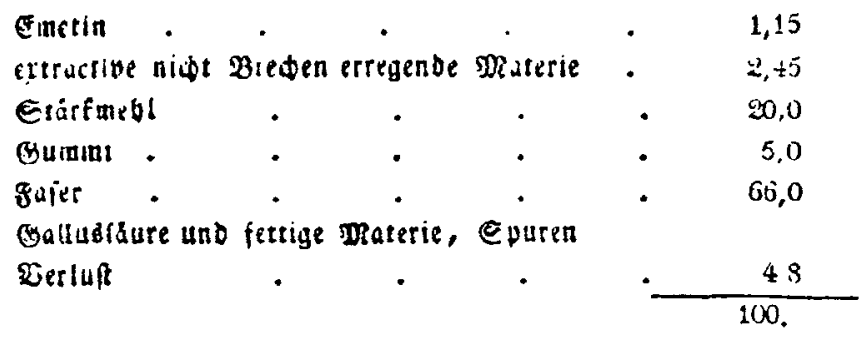

\section{Calicocca Ipecacuanha.}
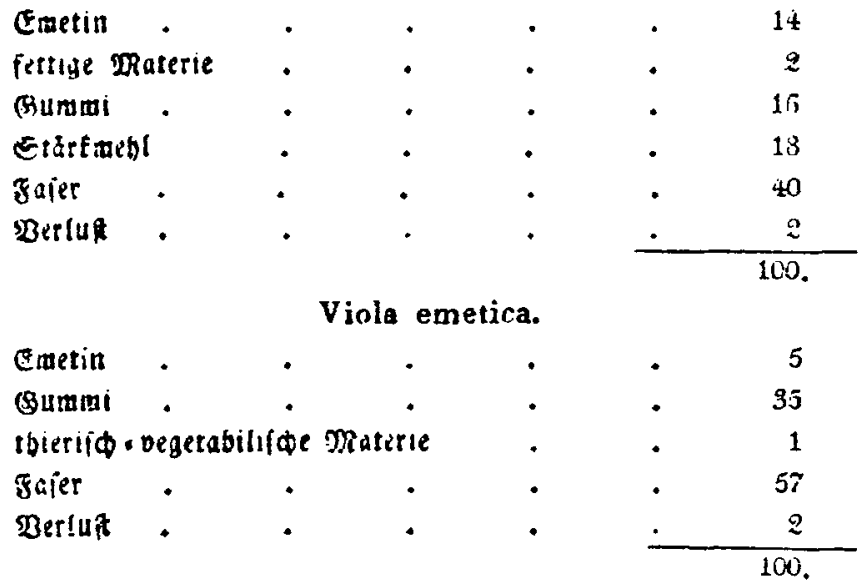

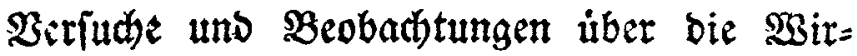
Eungen Des Mutterforns;

von

Dr. Lorinfer*).

2lus einer grofen Babl von Berfuळen uns Beobad;

agendi ratione atque usu. Lugduni Batavor. 1818.

Bullet. des sc. med. X. $\mathbf{3 0 0}$.

*) S. bas Berl bes ñeren Dr. Qorinfer unter obigen Tittl. Betlia 1824. Bergl. Bullet. des sc. med. IX. 271. 